\title{
The Fermentation Culprit
}

\author{
Helen Northcott* \\ Senior Core Professional, UK \\ *Corresponding author: Helen Northcott, Senior Core Professional, 308, 3420 Frederick Avenue, Vineland, Ontario L0R2C0, UK
}

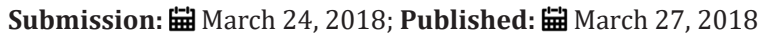

\section{Opinion}

Sitting down to a meal and a glass of wine may seem like you will be well nourished. Most do not care about its nutrients as long as it tastes good. At times indigestion bothers us and we reach for immediate relief. We may wonder what was eaten to cause heartburn and indigestion, but we really don't know. Well, today is your lucky day in that I will share with you the culprit of fermentation.

Realizing that those in the food industry want you to buy their product, they may withhold the truth about the processing process. Preserving food has been going on for centuries and the end always justified the means of doing it. Learning about the byproducts of fermentation was not given that much attention, nor was it suspected that it was harmful.

Here in Vineland, Ontario the peach and cherry trees will soon be blossoming and providing much beauty to enjoy for a few weeks. Soon the vineyards will be producing leaves and grapes for harvesting. Unfortunately, the fruit of the vine does not provide the biggest market for the farmers. Wineries are spotted all throughout the Niagara area turning it into a tourist area. Time spent In this lovely area can soon turn into troublesome times due to the alcohol content in the wine.

Food and beverages without any kind of fermentation is the most nutritious food for the body and the mind to maintain good health. Changing the molecular structure of food causes it not to be easily digested. Wine with its alcohol content attacks the brain and the body, harming its ability to function well. If you looked at a wine calorie chart you would see the calories ranging from 111 to 275 in a $6 \mathrm{oz}$ or $177 \mathrm{mi}$ glass or bottle. The sweeter the grapes the high the alcohol content in the wine.

Now for a look at the harmful effect of fermented foods. Fermentation has harmful properties and foods are heavily salted or preserved with vinegar which makes them harmful. When food ferments, decomposes or rots it produces waste products that produce bacteria which breaks down the food. There are several byproducts and one is alcohol and a small amount of it affects the cells of the body. Ammonia is a byproduct of fermentation and is as dangerous as a house cleaning agent. Fermentation also causes the waste product, vinegar which is acetic acid, and it gives the food a sour or sharp taste-a sure sign it should not be eaten. Vinegar prevents the digestion of food. If your muscles feel sore or stiff, it may be a result of lactic acid, so do not eat foods high in the waste byproducts.

Fermented foods are low in nutrition and when cut, chopped or sliced they start to ferment due to rapid oxidation. Eating the salad first is important so you enjoy their freshness and good nutritional content. B12 is lowered by fermented foods along with vitamins and minerals. Being aware of the damage of fermentation and its byproducts can help you make better choices when eating and drinking. Choose wisely and live well.
Creative Commons Attribution 4.0

International License

For possible submissions Click Here

Submit Article

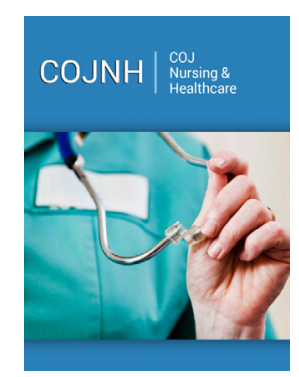

\section{COJ Nursing \& Healthcare}

Benefits of Publishing with us

- High-level peer review and editorial services

- Freely accessible online immediately upon publication

- Authors retain the copyright to their work

- Licensing it under a Creative Commons license

- Visibility through different online platforms 